\title{
Financing Higher Education through Student Loans: An Examination of Student Loan Take up and the Debt Burden among Ghanaian Tertiary Students
}

\author{
Stanley Kojo Daryand Harvey S. James, Jr
}

\begin{abstract}
:
This article examines the factors influencing demand for student loans from Ghana's Student Loan Trust Fund (SLTF) and the loan debt burden at completion using a sample of 400 final-year students in two higher education institutions in the country's Upper West Region. The results show that both the loan take up rate and the loan debt burden among students are relatively low. Demand for student loans and the loan debt burden is modelled as probit and Tobit (left censored), respectively. The results reveal that student age, household size, parents' occupation, salary, number of income sources, and the length of the study programme play a significant role in explaining demand for student loans and the loan debt burden at completion among tertiary students. These socio-economic factors should thus inform the design and administration of student loans.
\end{abstract}

Key words: student loan, loan debt, higher education, probit, Tobit, Ghana

Cet article étudie les facteurs qui influencent les demandes de prêts étudiants auprès du Student Loan Trust Fund (SLTF, Fonds pour le prêt étudiant) du Ghana et le poids de l'endettement à la fin des études, à partir d'un échantillon de 400 étudiants en dernière année dans deux établissements d'enseignement supérieur de la région du Haut Ghana Occidental. Les résultats démontrent que le nombre de demandes de prêt et le poids de

AвOUt THE AUthors: STANLEY KOJO DARY Department of Economics and Entrepreneurship Development, University for Development Studies, Box 520, Wa Campus, Ghana. Email: sdary@uds.edu.gh

HARVEY S. JAMES, JR Department of Agricultural and Applied Economics, University of Missouri, Columbia. Address: 146 Mumford Hall, Columbia, MO 652II, USA. Email: hjames@missouri.edu 
l'endettement sont relativement faibles chez les étudiants. Les demandes de prêts étudiants et le poids de l'endettement sont analysés respectivement avec des modèles probit et tobit (censure à gauche). Les résultats indiquent que l'âge des étudiants, la taille du foyer, la profession des parents, le salaire, le nombre de sources de revenus et la durée de la formation permettent en grande partie d'expliquer les demandes de prêts étudiants et le poids de l'endettement à la fin des études pour les étudiants issus de l'enseignement supérieur. Ces facteurs socio-économiques devraient avoir un impact sur la conception et la gestion des prêts étudiants.

Mots clés : prêt étudiant, endettement, études supérieures, probit, tobit, Ghana

\section{Introduction}

Higher education is indispensable for national economic growth and development. In her forward, Jee-Peng Tan (2006) observes that it is linked to productivity, competitiveness and economic development at both micro and macro-levels. International and donor organisations that hitherto focused on basic and secondary education are thus paying more attention to higher education (Bloom et al., 2006). Higher education has been found to produce both private and public returns and is supported by many governments around the world. At the individual level, it raises earning potential by improving a person's skills and probability of employment. It also offers opportunities for personal development and fulfillment through social networks and allows people to exercise a higher level of independence and creativity at work (Oreopoulos and Petronijevic, 2013). More broadly, Bloom et al. (2006, p. I) observe that "higher education may create greater tax revenue, increase savings and investment, and lead to a more entrepreneurial and civic society. It can also improve a nation's health, contribute to reduced population growth, improve technology and strengthen governance." Statistics show that both the number of people earning higher degrees and the earnings premium on higher degrees has increased. Heightened demand for skilled workers has been attributed to technological advancement (see Oreopoulos and Petronijevic, 2013; Avery and Turner, 2012).

As the demand for and the return on higher education has risen over time, so has its cost, putting pressure on public resources and individual households. Given its socio-economic importance in development, many countries around the world initially offered free tertiary education. However, rising costs and demand coupled with dwindling national resources resulted in cost-sharing between government and students becoming the dominant approach to finance higher education (Salmi, 2003). The down- 
side of this strategy is that economically disadvantaged populations are denied access to higher education (Woodhall, 2004). In response, governments introduced financial support systems, predominantly student loan schemes, to promote equal access to higher education and support human capital development (Salmi, 2003; Ziderman, 2013). While other support systems may be selective or designed to serve a particular constituency, student loan schemes are open to the broader student population, thus providing the largest chunk of funding (Salmi, 2003).) Loans enable student beneficiaries to delay payment for higher education to the post-graduation period when they are employed (Ziderman, 2013). They are regarded as investment loans because borrowers acquire knowledge as well as social and personal attributes that could enhance their economic performance and increase their earnings ( $\mathrm{Li}, 2 \mathrm{OI})$. An increasing number of college students are borrowing to finance their investment in human capital development through higher education (Avery and Turner, 2012).

Many student loan schemes have been established by governments and are publicly funded, with a few private student loans schemes, particularly in the United States (US) (Woodhall, 2004). Usher (2005) identified Australia, Canada, Germany, The Netherlands, New Zealand, Sweden, the United Kingdom (UK) (England and Wales), and the US as some of the largest Organization for Economic Cooperation and Development (OECD) countries with long-standing publicly funded student loan programmes. Such schemes are also common in African countries, including Ghana, Zambia, Kenya, Tanzania, Rwanda, Uganda, Botswana, Lesotho and South Africa.

The objectives of public student loan programmes vary. Ziderman (2013) outlined three objectives: (i) cost-sharing through the introduction of tuition and other user fees, (ii) social targeting - increasing poor and marginalised groups' access to higher education, and (iii) student independence - enabling students to depend less on their parents and relatives' financial contribution, especially when such contributions are not a legal requirement. Ziderman (2013) argues that student loan subsidies are more justifiable when the objective is social targeting. Loan repayment arrangements can be income contingent, where repayment is a fixed percentage of the beneficiary's income or mortgage-type (also time-dependent), where a fixed amount is paid in defined periods (Ziderman, 20I3; del Ray and Schiopu, 20I5; Chapman and Dearden, 20I7). Income contingent repayment schemes are more common around the world as mortgage type loans impose high repayment burdens on low income earners at the repayment phase (del Ray and Schiopu, 20I5). Interest rates on public student loan schemes are low through government subsidisation and repayment commences after completion of tertiary education once the beneficiary obtains employment (Woodhall, 2004). Recovery of loans has generally been a 
challenge. Shen and Ziderman's study of 44 loan schemes in 39 countries found an average recovery rate of 39 percent (cited in Ziderman, 2013).

Ghana's Student Loan Trust Fund (SLTF) provides loans to Ghanaian students in approved tertiary institutions. The SLTF has been in operation for over a decade. This article examines student loan take up and student loan debt under this scheme. Not all enrolled students in the approved higher education institutions take up loans and those that do may apply for and/or be approved for different amounts within the maximum set for their programmes. Furthermore, students may not take up loans consistently throughout their study programme. They may therefore graduate with different loan debt burdens. A key question is: what determines the probability of loan take up and loan debt burden at completion among tertiary students in Ghana? This article answers this question using survey data from final-year students in two higher education institutions: the University for Development Studies-Wa Campus and Wa Polytechnic. Few studies have examined this question empirically and they largely focus on students and loan schemes in developed countries (e.g., Oosterbeek and van den Broek, 2009; Schwartz and Finnie, 2002; Gayle, I994; I996) where the cost of higher education, financing opportunities, student loan arrangements and socio-economic circumstances are markedly different from those in developing countries, particularly Ghana. Previous studies in Ghana (e.g., Atuahene, 2008; Okae-Adjei, 2012; Yussif and Yussof, 2010) did not empirically examine the factors that make some students take up loans and variations in loan debt burden at completion. The results of this study may be useful for policy formulation relating to funding higher education and may also inform the operational focus and strategies of the SLTF loan scheme.

\section{Overview of the Cost-Sharing Policy and Student Loan Schemes in Ghana} Johnstone (2003) defined cost-sharing in higher education as "a shift in the burden of higher education costs from being borne exclusively or predominately by government, or taxpayers, to being shared with parents and students" (p. 35I). Cost sharing takes various forms including: (i) charging tuition and other user fees, (ii) freezing, reduction or elimination of student grants, (iii) reduction of effective grants represented by student loan subsidies, and (iv) changing public policies to shift enrollment from subsidised public higher education institutions to private higher education institutions that are tuition dependent (e.g., Johnstone, 2003; 2002; Ziderman, 2013). According to Ziderman (2013), cost-sharing is the dominant path pursued in many countries to augment funding for higher education and thus provides the basis for the spread of student loan schemes. It has been adopted in many developed and developing countries, including the 
US, Tanzania, Kenya, Austria, Canada, England, Finland, Morocco, Mexico, Germany, Hungary, Poland, Portugal, South Korea, Zimbabwe, Ethiopia, Australia, Japan and China. However, cost-sharing is driving many higher education students into indebtedness (del Ray and Schiopu, 20I5).

Ghana also transitioned from free higher education to cost-sharing arrangements and student loan schemes. There have been three dispensations of student loan schemes in Ghana: I97I-I972, I988-2005 and 2006-present. Higher education in Ghana was completely free until the late I96os when the government embarked on reforms driven by public resource constraints and the increased cost of funding higher education (McWilliam and Kwamena-Po, I975). The first reforms shifted some cost elements to students, which necessitated the establishment of a student loan scheme in I97I to provide funding at a zero interest rate (Addae-Mensah, 2000). The student loan scheme was abolished in 1972 following a military coup d'état that ushered in a new government as well as student demonstrations (Sawyerr 200I; Yussif and Yussof, 20I0). The second round of reforms formalised the cost-sharing policy following the economic recovery programme (ERP) launched by Ghana in the I980s under the World Bank. While government funded free tuition, all other costs were shifted to students. This greatly increased the financial burden of higher education, especially for poor students. The Social Security and National Insurance Trust (SSNIT) loan scheme was established in January I988 under PNDC Law 276 to provide financial resources at low interest rates to students. The aim was to increase access to higher education irrespective of economic class (ibid). Yussif and Yussof's (2010) longitudinal study of the impact of SSNIT loans on university enrolment found that access to loans significantly increased enrolment in Ghanaian universities. However, the SSNIT scheme faced a myriad of challenges that affected its sustainability including its inability to meet students' financial needs, loan accessibility constraints, operational inefficiency resulting from low repayment of loans, government's failure to pay interest subsidies and general student dissatisfaction with the scheme (Sawyerr, 200I).

In response to these challenges, a new student loan scheme, the SLTF, was initiated by an act of parliament in 2005 to replace the SSNIT loan scheme and commenced operations in 2006 . The SLTF is a public service organisation under the Ministry of Education. It is funded by a combination of public funding, loans from the SSNIT and private/corporate contributions (see Student Loan Trust Fund Act, 20II). To enhance proximity, the SLTF has zonal and campus offices across the country. Students pursuing accredited programmes in accredited private and public tertiary institutions are eligible for SLTF loans. In 20I5, students from II7 public and private tertiary institutions benefited from the scheme (Boamah, 20I5). 
Bokpe (20I8, May 3) reports that 90,000 students are currently on the SLTF scheme, with average annual new enrollment of 15,000 students for the period 20I4/20I5 - 20I6/20I7. Loan applications can be made at any time of the year on the STLF online system or at the scheme's offices. One guarantor that must be a SSNIT contributor is required. If a student is unable to get a SSNIT contributor to guarantee the loan, recognised religious bodies and corporate institutions as well as metropolitan, municipal and district assemblies (MMDAs) can serve as guarantors. The loan amounts are mean tested taking into account the programme of study and the student's financial need (Boamah, 20I5). They have been revised over the years in tandem with the increasing cost of education. Currently (20I7/I8 academic year), the minimum and maximum loan amounts stand at GHS 2,000 and GHS 3,000, respectively (Bokpe, 20I8). Table I presents the loan amounts for different programmes of study based on available 2015 statistics.

Table 1. Loan Amounts for Different Programmes

\begin{tabular}{|c|c|c|c|}
\hline Category & Minimum & Average & Maximum \\
\hline 3-year programs & $\mathrm{GH} \not 2,986.70$ & $\mathrm{GH} \$ 3,792.63$ & $\mathrm{GH} \not 7,585.26$ \\
\hline 4-year programs & $\mathrm{GH} \not 4,230.21$ & $\mathrm{GH} \Phi 5,371.69$ & $\mathrm{GH} \not 10,743.38$ \\
\hline 6-year programs & $\mathrm{GH} \not 7,182.79$ & $\mathrm{GH} \not \varnothing 9,121.01$ & $\mathrm{GH} \not 18,242.01$ \\
\hline
\end{tabular}

Source: Boamah (2015)

The interest rate on SLTF loans is indexed to the Bank of Ghana I82-day Treasury bill rate and capped at $\mathrm{I} 2$ percent. Before repayment, i.e., during the study period and the moratorium (one year national service plus one year post national service), borrowers pay the Bank of Ghana I82-day Treasury bill rate if the rate is below or equal to I2 percent. If it is above I2 percent, they pay I 2 percent interest, with the remainder absorbed by government. Interest is compounded annually before repayment. During the repayment phase, it is compounded semi-annually, with an additional 2 percent charge. The loans are subsidised in the sense that government absorbs the difference when the prevailing I82-day government of Ghana Treasury bill rate is above I2 percent. The SLTF scheme allows for various channels of repayment, including banks, cheque or cash payments at the SLTF head office, and cheques at its offices across the country (Boamah, 20I5). The SLTF Act makes it mandatory for both private and public sector employers to inform the SLTF of employees who are indebted to the scheme. They are also mandated to deduct monthly installments from the salaries of such employees and pay them to the SLTF (SLTF, 20I8). In 20I8, the Chief Executive Officer of the SLTF, Mr Kwaku Agyei Yeboah, 
stated that the average monthly repayment per beneficiary stood at about $\mathrm{GH} ₫ 50$, while the loan recovery rate was around 55 percent (Bokpe, 2018). The scheme has a Students Loan Protection Scheme (SLPS) that caters for loan liabilities in the event of a beneficiary's death or total permanent disability. It is funded by 0.5 percent deductions from loans issued to beneficiaries (SLTF, 20I5). Boamah (20I5) indicated that a total of 52 loans had been written off since the inception of the scheme.

A recent assessment by Okae-Adjei (20I2) suggests that, while challenges remain, the SLTF scheme is a marked improvement on the SSNIT loan scheme. Loan amounts are still inadequate to meet students' financial needs. For instance, maximum loan amounts are set for study programmes without considering that students in the same programme confront different financial constraints (Okae-Adjei, 20I2).

\section{Theoretical Background and Empirical Literature}

The human capital theory (Becker, I962) posits that education is an investment that generates higher expected returns to the individual over his/ her lifetime. Hence, student loans are considered investment loans rather than consumption ones where consumers maximise expected utility by the tenets of neoclassical economic theory (see e.g., Shwartz and Finnie, 2002; Oreopoulos and Petronijevic, 2013; Avery and Turner, 2012). Becker (I962) assumes that, in deciding to invest in human capital by attending college, a person would conduct a cost-benefits analysis of the investment and follow the investment decision criterion dictated by the standard economic theory of investment - that is invest if the discounted benefits exceed the discounted costs. The benefits are the expected future higher earnings accruing after completing higher education. The costs include the opportunity cost of higher education (earnings foregone while in college) and other direct education costs such tuition fees, transportation, etc. (Becker, I962; Li, 20I3; Avery and Turner, 2012). However, it is widely recognised that determining these costs and benefits and thus making an optimal investment decision is complex due to several factors, including incomplete information which may lead to underestimation or overestimation of costs and benefits, uncertainty about future economic and social conditions which may affect success in college, the cost of college and earning prospects, and behavioural idiosyncrasies such as degree of risk aversion which may affect optimal investment decisions (Oreopoulos and Petronijevic, 20I3; Li, 20I3).

Financing is part of the decision to obtain a higher education qualification. All things being equal, people will tend to follow the Pecking Order Model (Myers and Majluf, I984) that ranks internal financing first in the hierarchy of financing sources. Thus, students will prefer to finance 
their education using personal and family sources of income first and will consider taking loans if they face financial constraints. ${ }^{I}$ Loan take up and the amount borrowed are influenced by supply and demand factors whose effects are usually difficult to completely delineate (Li, 20I3). On the demand side, standard economic theory suggests that students who are not averse to risk, averse to debt and have high discount rates will be more inclined to take up student loans; they will also accumulate high loan debt (Oosterbeek and van den Broek, 2009). Empirical studies in various countries have examined the effect of these factors and other socio-economic variables such as age, gender, family background and income status on the probability of student loan take up and student loan debt. Johnes (I994) found that married students and female students in the UK are less likely to take up student loans. While he argues that working partners may provide support to their partners in school, female students may have lower lifetime earnings due to interrupted careers and discrimination, and may thus shy away from taking student loans. Conversely, Gayle's (I994; I996) study shows that single students in the UK are less likely to take student loans to finance their education.

Perali and Barzi (20II) found that loan aversion accounted more for Italian female university students not being interested in loans than the fact that they were not in need of loans, relative to male students. Students from low income families were more likely to take a loan due to liquidity constraints. The study also found higher propensity to take student loans among non-residential students and students who had worked before and/ or were working. In their study of higher education students' borrowing behaviour in The Netherlands, Oosterbeek and van den Broek (2009) found loan uptake rates to be low. Many students prefer to work part-time rather than take up government funded student loans. Moreover, students from low income families, those with high subjective discount rates and male students with high earning prospects were found to be more likely to take up student loans. Finally, students with a high degree of debt aversion and risk aversion are less likely to contract student loans. Booij, Leuven and Oosterbeek (20I2) also examined the determinants of loan experience (whether students had taken loans prior to study) in The Netherlands. They found that age, discount rate and risk tolerance increased the probability of loan take up. However, no evidence was found that gender differences and socio-economic background affect borrowing behaviour. Thus, students from disadvantaged backgrounds are not more likely to take up student loans than those from privileged ones. One explanation for this finding is the existence of government grant schemes that take financial background into consideration. After exposing students to information regarding student loans in a randomised experiment, the results showed that, this 
increased their factual knowledge, but not their loan take up, suggesting that a lack of information on loan conditions and processes is not a binding constraint on loan take up.

Christou and Haliassos (2006) investigated the factors that determine student loan take up and/or work in the US. Age was found to be correlated with less loan take up and more work. It was concluded that female students were less likely than men to rely exclusively on student loans but that gender related differences disappeared when it came to combining borrowing (loan take up) and work. Furthermore, married students were found to be less likely to engage in student loan contracts while those from low income family backgrounds were more likely to take up student loans. The authors attributed the low probability of married persons taking up loans to factors such as avoidance of a future debt burden on the spouse and family. Furthermore, after controlling for current support from family and grants, students from better resource-endowed families were found to be more likely to take up work than student loans. In another study in the US, Harrast (2004) found that age, and duration and field of study were significantly and positively related to student debt while student academic performance (GPA) was inversely related to loan debt. Relative to production/operations management, students who pursued special education, computer engineering, sociology, art history, and risk management and insurance carried higher loan debt. Gender was found to be unimportant in determining loan debt. Macy and Terry (20II) found that gender was unrelated to average student loan debt in US colleges and universities. While it was higher in larger institutions and those with higher tuition and other fees, average loan debt decreased with institutional endowment, class size and alumni giving. Tuition and other fees was the single most important determinant of average student loan debt. Williams et al. (20I6) found that the probability of student loan take-up among graduates of US veterinary medical colleges increased with being older student, female student, student with a child, non-specialised student and student with job offer(s) prior to graduation. The level of loan debt increased with a student being older, female, single, and attending a private university. Students who were residents (schooling in-state) and had received job offers prior to graduation had less loan debt. Menges and Leonhard's (20I6) study of three community colleges in the US examined the effect of time perspective, acculturation, and financial literacy on willingness to apply for student loans and found no significant results. They concluded that borrowing patterns may relate more to unique individual differences than sociocultural variables.

Schwartz and Finnie (2002) examined borrowing and repayment of student loans in Canada. The results suggest that higher expected future earnings (proxied by field of study) do not increase the likelihood of loan 
take up. Furthermore, no significant differences were found between female and male respondents in terms of the probability of taking up student loans. The researchers concluded that supply-side as opposed to demand-side factors are more important in determining the probability of loan take up. Bing (20I2) conducted a survey among 43I students at Hubei University of Technology in China on demand for state loans. The study employed the structural equation modeling technique and concluded that students from impoverished families are more likely to make loan applications than those from affluent families. More specifically, it is likely that students whose parents have low education levels, perform unskilled jobs and earn low wages will apply for loans. Finally, Haultain, Kemp and Chernyshenko's (20I0) investigation of the attitudes of students and prospective students at tertiary institutions in New Zealand to student debt found that the majority take up student loans. The results suggest that students' attitudes to student debt are determined by both fear of debt (the level at which students fear debt) and debt utility (the level at which students regard debt as useful for their education). In as much as students tend to fear incurring debt and may want to avoid it, at the same time they find debt useful in achieving their educational and career goals. While fear of debt diminishes as students progress up the educational ladder, their utility of debt remains constant (Haultain et al., 20IO).

In summary, various economic and non-economic factors influence loan take up and the loan debt burden among higher education students. The findings of previous studies differ in terms of these factors' significance, magnitude and direction of effect. Differences in the social, cultural and economic environments of the countries and student populations possibly account for observed differences in results. In Ghana, income levels are low and poverty rates are high. The country is grappling with high youth employment, including graduate unemployment. However, the prospect of earning a higher income is enhanced when one has a higher educational qualification and eventually finds a job. Therefore, in the case of Ghana, we expect that students' socio-economic background may play a key role in determining whether they take up SLTF loans and the amount of loan debt incurred on completion of higher education.

\section{Research Methods}

\subsection{Data and Variables}

The sample for the study was drawn from final-year students at two higher education institutions in the Upper West Region of Ghana, the University for Development Studies (UDS)-Wa Campus and Wa Polytechnic. The UDS-Wa Campus is one of the University for Development Studies' four campuses, with the other three located outside the Upper West Region, 
and the main administration in Tamale, Northern Region. The UDS-Wa Campus' programmes range from two-year diplomas to PhDs. The study focused on students pursuing four-year degree programmes. Wa Polytechnic mainly offers three-year Higher National Diploma programmes in various fields including business and applied sciences. These two institutions were the ones in this region approved for student loans under the SLTF during the period under study. Data collection took place in May 20I3. At this time, final-year students are on the point of completing their programmes and student loan applications and issuance of student loans are complete for the academic year. The students involved in the study were enrolled in academic programmes in 2009/2010 and 2010/201I at the UDS-Wa Campus and Wa Polytechnic, respectively.

Final year students were targeted in order to determine students' behaviour regarding student loans as they progress through their programmes and to determine student loan debt at completion. Stratified random sampling was employed to select the sample, with stratification based on gender and programme of study to ensure representativeness. The sampling units from each programme were selected at random and data was gathered by means of a self-administered questionnaire. Four hundred questionnaires were completed, 250 from UDS-Wa Campus and 150 from Wa Polytechnic. The UDS-Wa Campus has higher representation in the sample because of its larger final-year student population relative to Wa Polytechnic. Similarly, male student representation (250 students) is higher because men constitute the majority of students in the two institutions. The distribution of the sample by programme of study was as follows: 9I from Integrated Development Studies; 62 from Integrated Community Development; I7 from Real Estate; 30 from Planning; 45 from Integrated Business Studies; 5 from Integrated Management Studies; 20 from Agricultural Engineering; 63 from Accounting; 38 from Secretaryship and Management; and 29 from Marketing. The variation in numbers reflects the student population in the programmes. Only 398 observations were used for the econometric models as two observations were incomplete. The descriptive statistics of the variables drawn from the data are presented in Table 3, 4 and 5.

The dependent variables are DLoan and LoanDebt. DLoan is a binary variable; $\mathrm{I}$ if a student has taken a loan from the SLTF at least once during the academic programme and o otherwise. Loandebt is a continuous variable and represents the total amount of student loan (principal only) from the SLTF, accumulated per student at completion. The independent variables relate to students' personal characteristics, family background, income characteristics, and academic institution and programme characteristics. The variables and measurement are presented in Table 2. Since younger students are more likely to depend on their families, they are less 
likely to apply for student loans and should graduate with smaller loan debt. As stated by Harrast (2004), older students are likely to be less dependent on their family and may have a greater need for funds as necessities increase with age. Married students may have greater financial need than single students as they may be financially responsible for their spouses and children (if any). They are thus likely to take up student loans and graduate with higher loan debt. In general, women tend to be more risk averse than men and may take up loans only when it is absolutely necessary. It is therefore expected that male students will be more likely to take up student loans and graduate with higher loan debt. Due to limited residential facilities on the campuses of the two institutions, most students are compelled to stay off campus. Entry to campus residences is highly competitive. Aside from the higher cost of accommodation and utilities off campus, students incur high transportation costs commuting between campus and their off-campus residences. Furthermore, given that the public transportation system in the area is underdeveloped; most students living off campus are compelled to purchase motorbikes. It is thus expected that non-residential students will demand more student loans due to higher education expenditure and graduate with higher loan debt.

Being part of a large household suggests a high dependency ratio, especially if many household members are not employed. Students from large households are less likely to receive adequate internal financial support and will be more likely to take up student loans to finance their education and graduate with higher loan debt. Length of study, proxied by institution attended, may influence demand for student loans and loan debt. The UDS-Wa Campus runs four-year degree programmes while Wa Polytechnic offers three-year Higher National Diploma programmes. Therefore, students at the former institution spend more years obtaining their qualification and this is directly related to education expenditure (Harrast, 2004). UDS-Wa Campus students may have greater financial need than those at Wa Polytechnic and are more likely to take up student loans and graduate with higher loan debt. As the level of education and earnings are positively related (see, e.g., Oreopoulos and Petronijevic, 2013; Li, 20I3), parents/ guardians with a higher level of education are likely to earn more, which should enable them to financially support their children's education. Furthermore, since earnings in the formal sector are higher than those in the informal sector in Ghana, parents/guardians whose primary occupation falls under the formal sector are more likely to earn a higher income and be financially capable of supporting their children that are enrolled in tertiary programmes. Thus, it is expected that students whose parents/guardians have a higher level of education and those whose parents/guardians are primarily employed in the formal sector will express less demand for student 
loans and graduate with lower loan debt.

Students with scholarships, those that work while studying, and students with multiple sources of income are less likely to be financially constrained; they will more likely have less need for student loans and graduate with lower loan debt. Since poverty is more endemic in Ghana's three northern regions, it is also expected that students who originate outside these regions (in southern Ghana) will have less need for student loans. Unlike in some parts of the world, data are not available in Ghana on earnings by field of study. Hypotheses based on expected future earnings thus cannot be constructed (see, e.g., Harrast (2004) for the US).

Table 2. Variables and Measurement

\begin{tabular}{|c|c|c|}
\hline Variable & Description & Measurement \\
\hline DLoan & Loan take up & $\begin{array}{l}1 \text { if a student took a loan from SLTF at least once during } \\
\text { study programme, and o otherwise }\end{array}$ \\
\hline LoanDebt & Loan debt & $\begin{array}{l}\text { Total loan amount (principal only) accumulated by student at } \\
\text { completion (in } \mathrm{GH} \not \text { ) }\end{array}$ \\
\hline logAge & Student age & Natural logarithm of student age (in years) \\
\hline Gender & Gender of student & 1 if student is female and o if male \\
\hline Married & Marital status & 1 if student is married and o otherwise \\
\hline Residential & Residential status & 1 if student is residential and $\mathrm{O}$ if non-residential \\
\hline logHHSize & Household size & Natural logarithm of number of household members \\
\hline Institution & Length of study & 1 if UDS-Wa Campus student and o if Wa Polytechnic student \\
\hline Study & Field of study & $\begin{array}{l}\text { The fields of study are classified into three; Social Sciences } \\
\text { (SCHM), business (Business) and Applied Science } \\
\text { (ApScience). Each field is coded as dummy. }\end{array}$ \\
\hline PEduc & Parent Education & $\begin{array}{l}\text { Level of education of principal parent/guardian. Dummies } \\
\text { created for basic, secondary and tertiary education }\end{array}$ \\
\hline POccup & $\begin{array}{l}\text { Parent } \\
\text { Occupation }\end{array}$ & $\begin{array}{l}1 \text { if principal parent/guardian's major occupation is in the } \\
\text { formal sector and o if informal sector }\end{array}$ \\
\hline Scholarship & $\begin{array}{l}\text { Scholarship } \\
\text { received }\end{array}$ & $\begin{array}{l}1 \text { if student received scholarship during the study programme } \\
\text { and o otherwise }\end{array}$ \\
\hline logincomeS & Income sources & Natural logarithm of number of income sources \\
\hline Salary & Receiving salary & 1 if student is receiving salary and o otherwise \\
\hline Origin & Region of origin & $\begin{array}{l}1 \text { if student originates from southern Ghana and o if northern } \\
\text { Ghana (Upper West, Upper East and Northern region) }\end{array}$ \\
\hline
\end{tabular}




\subsection{Econometric Models}

\subsubsection{Probit Model}

Because demand for student loan is binary; $\mathrm{I}$ if a student took a loan at least once during the study programme and o otherwise, the probit model is employed. The empirical probit model for this study is expressed as:

$$
\begin{aligned}
\operatorname{Pr}\left(\text { Loan }_{\mathrm{i}}=1\right)=\beta_{0}+ & \beta_{1} \text { logAge }_{\mathrm{i}}+\beta_{2} \text { Gender }_{\mathrm{i}}+\beta_{3} \text { Married }_{\mathrm{i}}+\beta_{4} \text { Iog HHSize }_{\mathrm{i}} \\
& +\beta_{5} \text { Institution }_{\mathrm{i}}+\beta_{6} \text { Basic }_{\mathrm{i}}+\beta_{7} \text { Secondary }_{\mathrm{i}}+\beta_{8} \text { POccupation }_{\mathrm{i}} \\
& +\beta_{9} \text { Residential }_{\mathrm{i}}+\beta_{10} \text { Business }_{\mathrm{i}}+\beta_{11} \text { ApScience }_{\mathrm{i}}+\beta_{12} \text { Scholarship }_{\mathrm{i}} \\
& +\beta_{13} \text { Salary }_{\mathrm{i}}+\beta_{14} \text { log Income }_{\mathrm{i}}+\beta_{15} \text { Origin }_{\mathrm{i}}+\varepsilon_{\mathrm{i}}
\end{aligned}
$$

where $\beta_{0}$ is the constant term, $\beta_{i}^{\prime} s$ are parameters to be estimated, $X_{i}^{\prime} s$ are independent variables affecting the probability of student loan take up and $\varepsilon_{i}$ is the error term. All other variables are as defined in Table 2.

\subsubsection{Tobit Model (Left-Censored)}

The dependent variable, loan debt, is left censored with clustering at zero as some students do not take up loans from the SLTF during their period of study and graduate with zero loan debt. However, there is no right censoring as different students may graduate with different loan debt. The Tobit model proposed by James Tobin (1958) is appropriate for analysing censored data; it produces consistent estimates by using both the censored and uncensored information (Greene, 2002; Maddala, I983). The empirical Tobit model is specified as:

$$
\begin{aligned}
\text { LoanDebt }_{\mathrm{i}}=\beta_{0}+\beta_{1} \log \text { Age }_{\mathrm{i}}+\beta_{2} \text { Gender }_{\mathrm{i}}+\beta_{3} \text { Married }_{\mathrm{i}}+\beta_{4} \text { logHHSize } & +\beta_{5} \text { Institution }_{\mathrm{i}} \\
& +\beta_{6} \text { Basic }_{\mathrm{i}}+\beta_{7} \text { Secondary }_{\mathrm{i}}+\beta_{8} \text { POccupation }_{\mathrm{i}}+\beta_{9} \text { Residential }_{\mathrm{i}}+ \\
& +\beta_{10} \text { Business }_{\mathrm{i}}+\beta_{11} \text { ApScience }_{\mathrm{i}}+\beta_{12} \text { Scholarship }_{\mathrm{i}}+\beta_{13} \text { Salary }_{\mathrm{i}} \\
& +\beta_{14} \text { log IncomeS }_{\mathrm{i}}+\beta_{15} \text { Origin }_{\mathrm{i}}+\mu_{\mathrm{i}}
\end{aligned}
$$

(2)

where $\beta_{0}$ is the intercept term, $\beta_{1}-\beta_{15}$ are parameters relating to the predictor variables to be estimated and $\mu_{\mathrm{i}}$ is error term. All other variables are as defined in Table 2.

\section{Results and Discussion}

5.1. Descriptive Statistics

As shown in Table 3, about 34 percent of the respondents took a student loan from the SLTF during their three-/four-year study programme. 
Among these, 2 percent, II percent, 45 percent and 42 percent contracted a loan once, twice, and three and four times, respectively during their study programme. ${ }^{2}$ The loan take up rate is higher ( 42 percent) for students in fouryear study programmes than those in three-year programmes (2I percent). Differences in the cost of education may account for this observation. In the same graduating year (2013), about 69 percent of students graduating from four-year colleges in the US took up student loans (The Institute for College Access and Success, 20I4). Many factors may account for the low loan take up rate, including smaller loan amounts (see e.g., Bokpe, 20I8), no need for loans, high aversion to risk and debt, challenges with online loan application processes, and inability to make loan applications or unsuccessful loan applications due to failure to meet the requirements. On average, loan debt at completion is $\mathrm{GH} \$ 430.52$ (US\$280) and for the subset of students that took a loan, it averaged GHषI,257.00 (US\$820). ${ }^{3}$ Consistent with the loan take up rate, students in four-year programmes graduate with higher debt (GH455I/US\$35) than those in three-year programmes (GH\$229/US\$I49). For the subset of students that took a loan, it averaged GHфI,3I2 (US\$852) for students in four-year programmes and GH\&I,O75 (US\$698) for those in three-year programmes. The loan debt burden at completion is relatively low. The Institute for College Access and Success (20I4) reported an average loan debt of US\$28,400 among graduates of four-year colleges in the US in 2013. However, a direct comparison cannot be made due to differences in the cost of education, economic development, income (actual and potential) and overall living standards. In Ghana, students enrolled in public higher institutions generally do not pay tuition fees ${ }^{4}$; which reduces their financial burden and may contribute to the observed low loan debt burden. Nonetheless, for a developing country like Ghana, the recorded loan debts are important when analysed in relation to general income levels, particularly at the time these loans were received. Furthermore, the loan limits and means tests employed by the SLTF scheme (supply factors) may also affect the loan debt burden among students. In 2012/13, the minimum and maximum annual loan amount was $\mathrm{GH} \$ 300$ and $\mathrm{GH} \not 1,200$, respectively. 
Table 3. Student Loan Take Up and Loan Debt Burden

\begin{tabular}{|l|l|c|c|c|}
\hline & & DLoan & $\begin{array}{l}\text { Loan Debt } \\
\text { (in 1000 GH } \varnothing)\end{array}$ & $\begin{array}{l}\text { Loan Debt } \\
(1000 \mathrm{GH} \phi)^{\mathrm{a}}\end{array}$ \\
\hline Full Sample & Mean & .34 & .43052 & 1.25700 \\
\hline & Std. Dev. & .48 & .63787 & .38367 \\
\hline & Minimum & .00 & .00000 & .44000 \\
\hline UDS-Wa Campus & Maximum & 1.00 & 2.20000 & 2.20000 \\
\hline & Mean & .42 & .55122 & 1.31242 \\
\hline & Std. Dev. & .47 & .70101 & .40984 \\
\hline & Minimum & .00 & .00000 & .44000 \\
\hline Wa Polytechnic & Maximum & 1.00 & 2.20000 & 2.20000 \\
\hline & Mean & .21 & .22936 & 1.07513 \\
\hline & Std. Dev. & .41 & .45072 & .19437 \\
\hline & Minimum & .00 & .00000 & .73000 \\
\hline & Maximum & 1.00 & 1.50000 & 1.50000 \\
\hline
\end{tabular}

a Only for the subset of students who took up loans.

A mean group comparison test (t-test) is performed to determine if there are significant differences in mean loan debt burden based on gender, marital status, geographical origin, salary status, scholarship status, primary sector where parent is employed, student's residential status and length of programme of study (Table 4). Female students graduate with a significantly higher loan debt burden than male students. While the loan debt burden is still higher among female students when only the subset of students that took up a loan is considered, the difference is insignificant. The rest of the results show that students outside the three northern regions, those on scholarships, students in four-year programmes, and non-residential students graduate with a significantly higher loan debt burden. There is no significant difference in mean loan debt burden with respect to marital status, the sector where the parent is primarily employed and salary status. 
Table 4. Mean Group Comparison Test for Loan Debt

\begin{tabular}{|c|c|c|c|c|}
\hline Variable & Category & Mean & Mean Difference & $\mathrm{t}$-test \\
\hline \multirow[t]{2}{*}{ Gender } & Male & .31512 & \multirow[t]{2}{*}{30773} & \multirow[t]{2}{*}{.000} \\
\hline & Female & .62285 & & \\
\hline \multirow[t]{2}{*}{ Married } & Yes & .48695 & \multirow[t]{2}{*}{.07143} & \multirow[t]{2}{*}{.362} \\
\hline & No & .41552 & & \\
\hline \multirow[t]{2}{*}{ Origin } & South & .50082 & \multirow[t]{2}{*}{.14347} & \multirow[t]{2}{*}{.024} \\
\hline & North & .35735 & & \\
\hline \multirow[t]{2}{*}{ Salary } & Yes & .30823 & \multirow[t]{2}{*}{.14387} & \multirow[t]{2}{*}{.107} \\
\hline & No & .45210 & & \\
\hline \multirow[t]{2}{*}{ Scholarship } & Yes & .75060 & \multirow[t]{2}{*}{.34267} & \multirow[t]{2}{*}{.019} \\
\hline & No & .40793 & & \\
\hline \multirow[t]{2}{*}{ POccupation } & Formal & .38847 & \multirow[t]{2}{*}{.06444} & \multirow[t]{2}{*}{.337} \\
\hline & Informal & .45291 & & \\
\hline \multirow[t]{2}{*}{ Institution } & UDS Wa Campus & .55122 & \multirow[t]{2}{*}{.32186} & \multirow[t]{2}{*}{.000} \\
\hline & Wa Polytechnic & .22936 & & \\
\hline \multirow[t]{2}{*}{ Residential } & Yes & . 17707 & \multirow[t]{2}{*}{.40553} & \multirow[t]{2}{*}{.000} \\
\hline & No & .58260 & & \\
\hline
\end{tabular}

As shown in Table 5, the average final-year student in the sample was 25 years old and came from a household with approximately seven members, suggesting a high dependency ratio. About 2I percent of the students were married; this could have increased their need for financial support and thus a student loan. The majority ( 65 percent) of the students' parents worked in the informal sector. Students who received a salary and those on scholarships constituted I5 percent and 5 percent of the sample, respectively. Such students are less likely to be financially constrained and may have less need for a student loan. The average number of income sources for a student was 2.2, suggesting that the average student drew financial support from more than one source. The correlations of the variables used in the econometric models are presented in Table 6 . The correlation coefficients are very low, suggesting a low probability of multicollinearity problems in the econometric estimations. 
Table 5. Descriptive Statistics of Dependent and Independent Variables

\begin{tabular}{|c|c|c|c|c|c|}
\hline Variable & $\mathrm{N}$ & Mean & Std. Dev. & Minimum & Maximum \\
\hline Age & 400 & 25.14 & 3.27 & 20 & 47 \\
\hline Gender & 400 & .38 & .48 & o & 1 \\
\hline Married & 400 & .21 & .41 & o & 1 \\
\hline HHSize & 400 & 6.59 & 4.28 & 1 & 20 \\
\hline Institution & 400 & .63 & .48 & 0 & 1 \\
\hline Basic & 400 & .39 & .49 & o & 1 \\
\hline Secondary & 400 & .26 & .44 & o & 1 \\
\hline Tertiary & 400 & .35 & .48 & o & 1 \\
\hline POccupation & 400 & .35 & .48 & o & 1 \\
\hline Residential & 400 & .38 & .48 & o & 1 \\
\hline Business & 400 & .45 & .50 & ० & 1 \\
\hline ApScience & 400 & .05 & .22 & o & 1 \\
\hline $\mathrm{SCHM}$ & 400 & .50 & .50 & o & 1 \\
\hline Scholarship & 398 & .05 & .22 & o & 1 \\
\hline Salary & 400 & .15 & .36 & o & 1 \\
\hline Incomes & 400 & 2.17 & 1.37 & 1 & 8 \\
\hline Origin & 400 & .51 & .50 & o & 1 \\
\hline
\end{tabular}




\begin{tabular}{|c|c|c|c|c|c|c|c|c|c|c|c|c|c|c|c|c|c|}
\hline$\stackrel{n}{\sim}$ & & & & & & & & & & & & & & & & & - \\
\hline 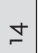 & & & & & & & & & & & & & & & & & ণุ \\
\hline$\stackrel{m}{n}$ & & & & & & & & & & & & & & & & & Oै \\
\hline$\stackrel{\sim}{\sim}$ & & & & & & & & & & & & & - & & & $\begin{array}{l}\text { O. } \\
\\
\end{array}$ & זَ. \\
\hline$=$ & & & & & & & & & & & & - & 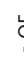 & & & $\frac{6}{i}$ & "י \\
\hline$\stackrel{ }{-}$ & & & & & & & & & & & - & 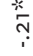 & 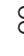 & & & 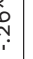 & 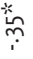 \\
\hline$a$ & & & & & & & & & & - & $\overbrace{}^{+}$ & $\stackrel{0}{\circ}$ & $\check{c}$ & & & $\tilde{c}$ & ๖ุ \\
\hline$\infty$ & & & & & & & & & - & นِ & $\stackrel{0}{\circ}$ & ô & 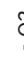 & & & ?ִ & 草 \\
\hline$n$ & & & & & & & & & $\hat{o}$ & ộ & ô & $\stackrel{0}{\circ}$ & 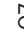 & & & ô. & อे \\
\hline 6 & & & & & & & & t & 䓵 & 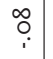 & $\stackrel{*}{*}$ & $\stackrel{\sim}{\circ}$ & 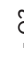 & & & ô & 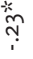 \\
\hline in & & & & & $r$ & 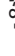 & & $\underline{y}$ & $\stackrel{0}{0}$ & 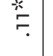 & $\stackrel{n}{\circ}$ & 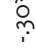 & $\tilde{c}$ & & & & "ִ \\
\hline$\nabla$ & & & & - & ন & & & ? & 㟔 & $\stackrel{w}{\stackrel{m}{*}}$ & $\stackrel{\text { Nִ }}{*}$ & Ð & 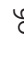 & & & & זִ \\
\hline$m$ & & & $r$ & o & : & & & ?. & oิ & 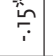 & ণิ & గ్ & $c$ & & & & $\begin{array}{l}\underline{6} \\
\dddot{1}\end{array}$ \\
\hline$N$ & & - & 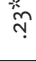 & 兴 & o & 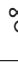 & & ? & ب. & "ִ & $\bigcap_{i}$ & $\overbrace{i}^{+}$ & $\alpha$ & & & $\underline{b}$ & סֶ \\
\hline- & $r$ & 蒙 & 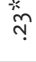 & F & Ø̊ & 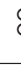 & & ? & ঃ & 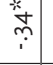 & ô. & б. & $\AA$ & & & hi & $\hat{o}$ \\
\hline & 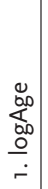 & 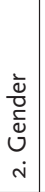 & 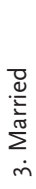 & 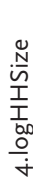 & 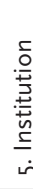 & $\begin{array}{l}y \\
y \\
\alpha \\
c\end{array}$ & & •. & 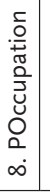 & 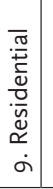 & $\begin{array}{l}\tilde{y} \\
\stackrel{5}{v} \\
\stackrel{n}{0} \\
\stackrel{0}{0}\end{array}$ & 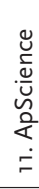 & 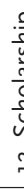 & & & & 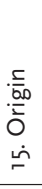 \\
\hline
\end{tabular}




\subsection{Determinants of Demand for Student Loans}

Table 7 presents the hierarchical binary probit regression results. Model I contains the variables on students' personal characteristics. In model 2, students' family background characteristics are added while students' income variables are added in model 3. Finally, model 4 is the full model where students' academic institution and programme characteristics are added. The significance of the Likelihood Ratio statistics (prob>ch2=.000) is indicative that the models are well fitted. Robust standard errors are reported. Gender and region of origin are only significant (models I, 2 and 3) when students' academic and programme characteristics are not incorporated. Age is significant and positive with a marginal effect of 8.40 on demand for student loan (model 4). This shows that older students are more likely to take up a student loan and is similar to Booij et al.'s (20I2) findings in The Netherlands. Family financial support declines as students grow older, requiring that they bear their own financial responsibilities and student loans can be a crucial source. The probability of taking up a loan increases with being married, with a marginal effect of .Io. Married students are likely to carry a higher financial burden due to the added responsibility of caring for their families while in school. Schooling also introduces additional expenditure to the family and taking up a student loan may help to reduce liquidity constraints. Similarly, Gayle (1994; 1996) found high demand for loans among married students in the UK. In contrast, studies by Johnes (I994) in the UK and Christou and Haliassos (2006) in the US found demand for student loans to be high among single students. Consistent with the a priori expectation, students on the UDS-Wa Campus (four-year programmes) are more likely to take up a student loan than those at Wa Polytechnic (threeyear programmes). An additional year in college, increases educational expenditure and hence, demand for student loans.

Household size is significant and positive, indicating that students from larger households are more likely to take up a student loan. This may result from inadequate family support due to the high dependency ratio. Parent occupation is significant and negative; suggesting that demand for student loans is higher among students whose parents' primary occupation lies in the informal sector. The likelihood of taking up a student loan decreases by .88 for students whose parents primarily work in the formal sector of the Ghanaian economy. Due to low earnings, parents in the informal sector may not have the financial muscle to support their wards' higher education, which may explain the greater need for student loans among such students. A negative relationship between family income status and demand for student loans has been widely reported in the literature. Perali and Barzi (20II), Oosterbeek and van den Broek (2009), Christou and Haliassos (2006), and Bing (2012) found that students from low income 
families in Italy, The Netherlands, the US and China, respectively, have higher demand for student loans.

Against the a priori expectation, receipt of a scholarship increases demand for student loans and the effect is significant at the 5 percent level. This suggests that students that receive scholarships may come from poor families that cannot offer financial support, requiring that they take up a student loan to supplement their scholarship. It also suggests that scholarships may be insufficient to cover expenses throughout the study programmes. Students that receive a salary while studying are less likely to take up a student loan. Receiving a salary suggests that the student is either on paid study leave or is working while studying. Consistent with economic reasoning, receiving a regular salary improves a student's liquidity and reduces the need to take up a student loan. However, Perali and Barzi (20II) found evidence to the contrary in Italy, where the likelihood of taking a loan increased with being a working student. Perali and Barzi (2OII) also found that students who had worked before, had a higher propensity to take up a student loan. The number of income sources is significant and negative, indicating that the probability of taking up a student loan decreases as the student's number of income sources increases. Students with multiple income sources have less need to take up a student loan. For instance, a student may receive support from their parents, other working family members and distant relatives. 
Table 7. Determinants of Loan Take Up (Binary Probit)

\begin{tabular}{|c|c|c|c|c|}
\hline & 1 & 2 & 3 & 4 \\
\hline DLoan & $\mathrm{dy} / \mathrm{dx}$ & $d y / d x$ & $d y / d x$ & $\mathrm{dy} / \mathrm{dx}$ \\
\hline logAge & $\begin{array}{l}7.06 * * * \% \\
(1.27)\end{array}$ & $\begin{array}{l}4.96 \% * * * \\
(1.09)\end{array}$ & $\begin{array}{l}5.52^{* * * *} \\
(.1 .15)\end{array}$ & $\begin{array}{l}8.40 * \cdots * * \\
(1.67)\end{array}$ \\
\hline Gender & $\begin{array}{l}.72 * * * * \\
(.15)\end{array}$ & $\begin{array}{l}.50 * * * \\
(.22)\end{array}$ & $\begin{array}{l}.61 * k * ; \\
(.23)\end{array}$ & $\begin{array}{l}.16 \\
(.32)\end{array}$ \\
\hline Married & $\begin{array}{l}-.64^{* * * * k} \\
(.20)\end{array}$ & $\begin{array}{l}-.21 \\
(.29)\end{array}$ & $\begin{array}{l}.25 \\
(.35)\end{array}$ & $\begin{array}{l}.10 * * \\
(.44)\end{array}$ \\
\hline logHHSize & & $\begin{array}{l}3.57^{* * * k} \\
(.50)\end{array}$ & $\begin{array}{l}3.53^{* * * *} \\
(.54)\end{array}$ & $\begin{array}{l}5.36 \% * * \\
(.91)\end{array}$ \\
\hline Origin & & $\begin{array}{l}1.30 * * * \\
(.26)\end{array}$ & $\begin{array}{l}1.38 * * * * \\
(.25)\end{array}$ & $\begin{array}{l}.46 \\
(.46) \\
\end{array}$ \\
\hline Basic & & $\begin{array}{l}-.19 \\
(.30)\end{array}$ & $\begin{array}{l}-.29 \\
(.34)\end{array}$ & $\begin{array}{l}-.36 \\
(.43)\end{array}$ \\
\hline Secondary & & $\begin{array}{l}.20 \\
(.30)\end{array}$ & $\begin{array}{l}.09 \\
(.34)\end{array}$ & $\begin{array}{l}-.20 \\
(.39)\end{array}$ \\
\hline POccupation & & $\begin{array}{l}-1.65^{* * *} \\
(.30)\end{array}$ & $\begin{array}{l}-.65^{* * *} \\
(.32)\end{array}$ & $\begin{array}{l}-.88 * \\
(.46) \\
\end{array}$ \\
\hline Scholarship & & & $\begin{array}{l}.96 \% \\
(.55)\end{array}$ & $\begin{array}{l}1.85^{* * *} \\
(.83)\end{array}$ \\
\hline Salary & & & $\begin{array}{l}-1.27^{* \ldots * *} \\
(.44)\end{array}$ & $\begin{array}{l}-2.06 * * * k \\
(.64)\end{array}$ \\
\hline logIncomeS & & & $\begin{array}{l}-.54 \\
(.43)\end{array}$ & $\begin{array}{l}-2.24^{* * *} \\
(.66)\end{array}$ \\
\hline Institution & & & & $\begin{array}{l}3.60 * * * * \\
(.68)\end{array}$ \\
\hline Residential & & & & $\begin{array}{l}.16 \\
(.34)\end{array}$ \\
\hline Business & & & & $\begin{array}{l}-.79 \\
(.55) \\
\end{array}$ \\
\hline ApScience & & & & $\begin{array}{l}-1.40 * \\
(.75)\end{array}$ \\
\hline Constant & $-23.43^{* * * *}$ & $-.24 .31 * * *$ & $-25.58 * x *$ & $-38.43 * * *$ \\
\hline Wald & $62.20 * x *$ & $109.75 * * *$ & $137.36 * * *$ & $56.79 * * * *$ \\
\hline Pseudo $\mathrm{R}^{2}$ & .30 & .69 & .71 & .87 \\
\hline AIC & 369.09 & 175.92 & 169.81 & 99.68 \\
\hline $\mathrm{BIC}$ & 385.06 & 211.85 & 217.65 & 163.47 \\
\hline $\mathrm{N}$ & 400 & 400 & 398 & 398 \\
\hline
\end{tabular}

Robust standard errors are reported (in parentheses). $*$, ** and $* * *$ depict significance at 10\%, $5 \%$ and $1 \%$ level, respectively. 


\subsection{Determinants of the Student Loan Debt Burden}

The Tobit results on the determinants of the student loan debt burden are presented in Table 8 . Tobit models are estimated for the full sample (models I, 2, 3, and 4) and for the UDS-Wa Campus (model 5) and Wa Polytechnic (model 6). All the models are statistically significant at the one percent level. Overall, the main results (model 4) are similar to the probit results presented in Table 7 . They show that older students accumulate higher loan debt during their study programme. Thus, older students with less working years graduate with higher loan debt than younger students who have more working years. Students from larger households also graduate with higher loan debt. This is due to the fact that such households suffer financial constraints. Loan debt increases with the duration of the programme of study. Students at the UDS-Wa Campus accumulate higher loan debt than students in Wa Polytechnic due to an additional year of study. An additional year of study increases the student loan debt burden by i.I8.

Students whose parents have basic education will accumulate less loan debt than those whose parents have tertiary education. This result is interesting as earnings should rise with the level of education and better educated parents should offer more financial support to their wards, reducing their need for student loans and consequently loan debt. Furthermore, students in applied science programmes will accumulate less loan debt than those in social science ones. This finding is explained by the fact that the applied science programme is a three-year programme that is only offered at Wa Polytechnic. The results thus cannot be interpreted directly as an effect of field of study on loan debt. However, students whose parents primarily work in the informal sector will accumulate higher loan debt at completion. Students receiving salaries while studying and those with more income sources will graduate with lower levels of loan debt; this is indicated by the significant and negative marginal effect of Salary and logIncomeS, respectively. When the results of the UDS-Wa Campus (model 5) and Wa Polytechnic (Model 6) are compared, household size and parents' occupation are significant in both cases. However, there are variations in the significance of the other variables. Age, parents' education status and number of income sources are significant for the UDS-Wa Campus while residential status, business programme and receipt of scholarship are significant for Wa Polytechnic. 
24 STANLEY KOJO DARY AND HARVEY S. JAMES, JR

Table 8. Determinants of Loan Debt (Left Censored Tobit)

\begin{tabular}{|c|c|c|c|c|c|c|}
\hline \multirow{2}{*}{ LoanDebt } & \multicolumn{4}{|l|}{ All } & \multirow{2}{*}{$\begin{array}{l}\text { UDS Wa } \\
\text { Campus } \\
5\end{array}$} & \multirow{2}{*}{$\begin{array}{l}\text { Wa } \\
\text { Polytechnic } \\
6\end{array}$} \\
\hline & 1 & 2 & 3 & 4 & & \\
\hline logAge & $\begin{array}{l}7.87^{* * x \cdot k} \\
(.96)\end{array}$ & $\begin{array}{l}3.84^{* * * k} \\
(.70)\end{array}$ & $\begin{array}{l}3.94^{* * * *} \\
(.68)\end{array}$ & $\begin{array}{l}2.97^{* k *} \\
(.56)\end{array}$ & $\begin{array}{l}5.95^{* * * *} \\
(.83)\end{array}$ & $\begin{array}{l}.42 \\
(.40)\end{array}$ \\
\hline Gender & $\begin{array}{l}.71^{* * * *} \\
(.16)\end{array}$ & $\begin{array}{l}.37^{*+2 k *} \\
(.11)\end{array}$ & $\begin{array}{l}.38 \% \text {. } \\
(.11)\end{array}$ & $\begin{array}{l}.12 \\
(.09)\end{array}$ & $\begin{array}{l}.06 \\
(.10)\end{array}$ & $\begin{array}{l}-.06 \\
(.09)\end{array}$ \\
\hline Married & $\begin{array}{l}-.57 * * * k \\
(.20)\end{array}$ & $\begin{array}{l}-.20 \\
(.14)\end{array}$ & $\begin{array}{l}-.05 \\
(.15)\end{array}$ & $\begin{array}{l}.11 \\
(.11)\end{array}$ & $\begin{array}{l}.08 \\
(.13)\end{array}$ & $\begin{array}{l}.08 \\
(.12)\end{array}$ \\
\hline logHHSize & & 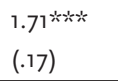 & $\begin{array}{l}1.55^{* * * *} \\
(.17)\end{array}$ & $\begin{array}{l}1.49^{* * * * *} \\
(.14)\end{array}$ & $\begin{array}{l}.79^{* \ldots+k} \\
(.14)\end{array}$ & $\begin{array}{l}2.57^{* * * * k} \\
(.26)\end{array}$ \\
\hline Origin & & $\begin{array}{l}.61 * k * k \\
(.12)\end{array}$ & $\begin{array}{l}.61 \% k+k \\
(.12)\end{array}$ & $\begin{array}{l}-.04 \\
(.11)\end{array}$ & $\begin{array}{l}-.04 \\
(.11)\end{array}$ & $\begin{array}{l}.03 \\
(.17)\end{array}$ \\
\hline Basic & & $\begin{array}{l}-.42^{* k * k} \\
(.14)\end{array}$ & $\begin{array}{l}-.48 * * * * \\
(.15)\end{array}$ & $\begin{array}{l}-.36 * * * \\
(.13)\end{array}$ & $\begin{array}{l}-.37^{*+1 \cdot k} \\
(.14)\end{array}$ & $\begin{array}{l}.05 \\
(.12)\end{array}$ \\
\hline Secondary & & $\begin{array}{l}-.02 \\
(.14)\end{array}$ & $\begin{array}{l}-.07 \\
(.14)\end{array}$ & $\begin{array}{l}-.08 \\
(.10)\end{array}$ & $\begin{array}{l}-.05 \\
(.11)\end{array}$ & $\begin{array}{l}.01 \\
(.11)\end{array}$ \\
\hline POccupation & & $\begin{array}{l}-.40 * * * \\
(.14)\end{array}$ & $\begin{array}{l}-.38 * \cdots * x \\
(.14)\end{array}$ & $\begin{array}{l}-.22 * * \\
(.11)\end{array}$ & $\begin{array}{l}-.28 * * * * \\
(.11)\end{array}$ & $\begin{array}{l}.37^{* * *} \\
(.14)\end{array}$ \\
\hline Scholarship & & & $\begin{array}{l}.23 \\
(.27) \\
\end{array}$ & $\begin{array}{l}.24 \\
(.28) \\
\end{array}$ & $\begin{array}{l}.29 \\
(.25) \\
\end{array}$ & 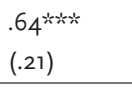 \\
\hline Salary & & & $\begin{array}{l}-.46 \% * \\
(.21)\end{array}$ & $\begin{array}{l}-.50 * * * * \\
(.17)\end{array}$ & $\begin{array}{l}-.17 \\
(.15)\end{array}$ & $\begin{array}{l}-.05 \\
(.18)\end{array}$ \\
\hline logIncomeS & & & $\begin{array}{l}-.31 \\
(.22)\end{array}$ & $\begin{array}{l}-.58 * * * * \\
(.16)\end{array}$ & $\begin{array}{l}-.71^{* * * *} \\
(.16)\end{array}$ & $\begin{array}{l}.14 \\
(.19)\end{array}$ \\
\hline Institution & & & & $\begin{array}{l}1.20 * k * k \\
(.17)\end{array}$ & & \\
\hline Residential & & & & $\begin{array}{r}-.09 \\
(.11) \\
\end{array}$ & $\begin{array}{l}-.04 \\
(.14)\end{array}$ & $\begin{array}{l}-.33 \% * k \\
(.14)\end{array}$ \\
\hline Business & & & & $\begin{array}{l}-.05 \\
(.14)\end{array}$ & $\begin{array}{l}-.11 \\
(.13)\end{array}$ & $\begin{array}{l}1.00 * * * \% \\
(.13)\end{array}$ \\
\hline ApScience & & & & $\begin{array}{l}-.53^{*} \\
(.27)\end{array}$ & & \\
\hline Constant & $-26 * * *$ & $-16.15 * * * *$ & $-15.81 * * *$ & $-12.60 * * * *$ & 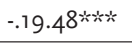 & $-8.81 * * * *$ \\
\hline F Stat & $48.52 * * * *$ & $52.00 * * * *$ & $38.51 \% * *$ & $36.56 * * *$ & $36.13 * x *$ & $14.45^{* * * *}$ \\
\hline Pseudo $\mathrm{R}^{2}$ & .20 & .45 & .46 & .59 & .60 & .94 \\
\hline $\mathrm{N}$ & 400 & 400 & 398 & 398 & 250 & 148 \\
\hline
\end{tabular}

Robust standard errors are reported (in parentheses). $*$, $* *$ and $* * *$ depict significance at 10\%, $5 \%$ and $1 \%$ level, respectively. 


\section{Conclusion and Policy Recommendations}

The Ghanaian government established the SLTF to provide loans to students enrolled in approved tertiary institutions to finance their education. This article examined the factors affecting demand for student loans and the loan debt burden among students. The data were collected via a survey of final-year students at two higher education institutions that are approved for student loans under the SLTF in the Upper West Region, the University for Development Studies-Wa Campus and Wa Polytechnic. The study found that demand for student loans is relatively low, with about 34 percent of students taking up a loan from the STLF at least once during their study programme. The average loan debt burden is also relatively low. Demand for student loans was modelled as probit and loan debt as Tobit (left censored). The econometric results are generally consistent with what standard economic theory would predict. Important determinants in explaining demand for student loans and the loan debt burden at completion included student age, household size, parent's occupation, salary status, the number of income sources, and the length of the programme of study. Receipt of a scholarship was also found to be important in explaining demand for student loans, but unimportant in relation to loan debt. Students' socioeconomic background explained student behaviour regarding student loans. The socio-economic factors identified should thus inform the design and administration of student loans. Students from low socio-economic backgrounds accumulate more loan debt, and, given that graduate unemployment has risen to high levels in Ghana, such students are also less likely to find jobs at least in the short run. This could delay loan debt repayment, further increasing their debt burden since interest on student loans is compounded at repayment. In general, the loan amounts defined by the SLTF appear inadequate relative to the cost of tertiary education in Ghana such that, without personal sources of income or parents/relatives' financial support, a student cannot depend on loans from the scheme to fully finance their education. Increasing the loan amount, especially for students in need of more financial support, could increase the socio-economic impact of the SLTF scheme. This may require innovative approaches to raise more funds to finance the operations of the scheme. 


\section{Endnotes}

I. If scholarships are available, they will rank before personal and family sources of financing in the hierarchy.

2. The results are not shown here but are available on request. Only students on the UDS Wa Campus took a loan four times.

3. An exchange rate of $\mathrm{I} .54 \mathrm{GH} \not$ (Ghana cedi) to US\$I is computed from average official exchange rates for 2009, 20I0, 20II and 2012 (see data. worldbank.org) and used in the conversion since the loan receipt covered this period.

4. Except for students admitted as fee paying students. Students in private higher education pay tuition fees.

\section{Acknowledgements}

We sincerely thank Ankrah Dominic Kwasi, Otoo Gideon, Owoo Elizebeth, Owusu Agyei Kwame and Owusu Francis Acheaw for collecting the data, some of which is used in this article. We also thank the reviewers for their constructive suggestions.

\section{References}

Addae-Mensah, I. (2000). Education in Ghana: A Tool for Social Mobility or Social Stratification? Ghana Academy of Arts and Sciences.

Atuahene, F. (2008). The challenge of financing higher education and the role of student loans scheme: An analysis of the Student Loan Trust Fund (SLTF) in Ghana. Higher Education 56(4), 407-421. doi: https:// doi.org/I0.1007/sio734-007-9I0I-5

Avery, C., and Turner, S. (2012). Student loans: do college students borrow too much - or not enough? The Journal of Economic Perspectives 26(I), I65-I92. doi: https://doi.org/Io.I257/jep.26.I.I65

Becker, G. S. (1962). Investment in human capital: A theoretical analysis. The Journal of Political Economy 70(5), 9-49. doi: https://doi. org/10.1086/258724

Bing, Z. (20I2). A study of state educational loan demand diversity and its influencing paths - An empirical analysis based on SEM model. Energy Procedia 17, I932-I939. doi: https://doi.org/ıo.IoI6/j.egypro. 2012.02.335

Bloom, D. E., Canning, D., and Chan, K. (2006). Higher education and economic development in Africa (Vol. IO2). Washington DC: World Bank. Available at: http://www.arp.harvard.edu/AfricaHigherEducation/ Reports/BloomAndCanning.pdf

Boamah, S. A. (2015). Students Loan Trust Fund (SLTF) at 10: A Decade of dedicated service to the Ghanaian tertiary students. The Launch of the $1 \mathrm{I}^{\text {th }}$ Anniversary, Accra International Conference Center, Accra, Ghana. 
Available at: https://www.sltf.gov.gh/wp-content/uploads/2015/o9/ CEO_s_Final_Pre_Press_Launch-Friday_itth_Sep_20I5_20I5.pdf

Bokpe, S. J. (2018, May 3). Students loan increase puts pressure on fund. Daily Graphic.

Retrieved from: https://www.graphic.com.gh/news/general-news/students -loan-increase-puts-pressure-on-fund.html.

Booij, A. S., Leuven, E., and Oosterbeek, H. (2012). The role of information in the take-up of student loans. Economics of Education Review 31(I), 33-44. doi: https://doi.org/Io.IoI6/j.econedurev.20II.08.009

Chapman, B., and Dearden, L. (20I7). Conceptual and empirical issues for alternative student loan designs: the significance of loan repayment burdens for the US. Centre for Global

Higher Education working paper series, No. I7. London, UK.

Christou, C., and Haliassos, M. (2006). How do students finance human capital accumulation? The choice between borrowing and work. Journal of Policy Modeling 28(I), 39-51. doi: https://doi.org/ıо.ıог/j. jpolmod.2005.07.006

del Rey, E., and Schiopu, I. (20I5). Student debt in selected countries. European Expert

Network on Economics of Education Analytical Report, No. 25. Available at: www.eenee.de/dms/EENEE/Analytical_Reports/EENEE_AR25.pdf

Gayle, V. (I996). The determinants of student loan take-up in the United Kingdom: another gaze. Applied Economics Letters 3(I), 25-27. doi: https://doi.org/Io.Io80/758525510

Gayle, V. (I994, December). The student experience: Factors influencing taking out loans. SRHE Annual Conference, York University, Canada.

Greene, W. H. (2002). Econometric analysis. Prentice Hall.

Harrast, S. A. (2004). Undergraduate borrowing: A study of debtor students and their ability to retire undergraduate loans. Journal of Student Financial Aid 34(I), 2I-37.

Haultain, S., Kemp, S., and Chernyshenko, O. S. (2010). The structure of attitudes to student debt. Journal of Economic Psychology 31(3), 322-330. doi: https://doi.org/Io.IoI6/j.joep.2010.01.003

$\mathrm{Li}, \mathrm{W}$. (2013). The economics of student loan borrowing and repayment. Business Review Q3, I-IO.

Johnes, G. (I994). The determinants of student loan take-up in the United Kingdom. Applied Economics 26(го), 999-1005. doi: https://doi. org/I0.1080/00036849400000107

Johnstone, D. B. (2003). Cost sharing in higher education: Tuition, financial assistance, and accessibility in a comparative perspective. Sociologický časopis/Czech Sociological Review 39(3), 35I-374.

Johnstone, B. (2002). Challenges of financial austerity: Imperatives and 
limitations of revenue

diversification in higher education. The Welsh Journal of Education 11(I), I8-36.

Macy, A., and Terry, N. (20II). The determinants of student college debt. Southwestern Economic Review 34, I5-26.

Maddala, G. S. (1986). Limited-dependent and qualitative variables in econometrics (No. 3). New York: Cambridge University Press.

McWilliam, H. O. A., and Kwamena-Po, M. A. (I975). The development of education in Ghana: An outline. London: Longman Group Ltd.

Menges, K. K., and Leonhard, C. (20I6). Factors that affect willingness to borrow student loans

among community college students. Journal of Student Financial Aid 46(2), 79-94.

Myers, S. C., and Majluf, N. S. (I984). Corporate financing and investment decisions when firms have information that investors do not have. Journal of Financial Economics 13(2), I87-221. doi: https://doi. org/ıo.IOI6/0304-405X(84)90023-0

Okae-Adjei, S. (2OI2). Student loans as an alternative to funding higher education in Ghana: an analysis of the students' loan trust fund. Interdisciplinary Journal of Contemporary Research in Business 4(6), 282-292.

Oosterbeek, H., and van den Broek, A. (2009). An empirical analysis of borrowing behavior of higher education students in the Netherlands. Economics of Education Review 28(2), I70-I77. doi: https://doi. org/ıo.ıoi6/j.econedurev.2008.01.005

Oreopoulos, P., and Petronijevic, U. (2013). Making college worth it: A review of the returns to higher education. The Future of Children 23(I), 4I-65. doi: https://doi.org/I0.I353/foc.20I3.000I

Perali, F., and Barzi, F. (20II). Equity and access to tertiary education: Demand for student loans in Italy. doi: https://doi.org/Io.2139/ssrn.I7I3989

Salmi, J. (2003). Student loans in an international perspective: The World Bank experience. World Bank Working paper 27295. Available at: http://documents.worldbank.org/curated/en/I4900I468765578I8I/ pdf/272950studentrloans.pdf

Sawyerr, A. (200I). The student loans scheme: Two decades of experience in Ghana. National Council for Tertiary Education. Tertiary Education Series 1(3), I-I2.

Schwartz, S., and Finnie, R. (2002). Student loans in Canada: An analysis of borrowing and repayment. Economics of Education Review 21(5), 497512. doi: https://doi.org/IO.IOI6/SO272-7757(OI)0004I-3

Student Loan Trust Fund (20I8). Employer's Notice. Available at: https:// www.sltf.gov.gh/employers-notice/

Student Loan Trust Fund (2015). 2015 Annual report. Available at: https:// 
www.sltf.gov.gh/wp-content/themes/sltf/sltfwebface/other\%2o resources/20I5ANNUALREPORT.pdf

Student Loan Trust Fund Act (20II). Act 820. Available at: http://www.sltf. gov.gh/downloads/Student\%20Loan\%20Fund\%20Act\%2020II.pdf

Tan, J. (2006). Forward. In: Bloom, D., Canning, D., and Chan, K. Higher education and economic development in Africa (pp. i-ii). Available at: http://www.arp.harvard.edu/AfricaHigherEducation/Reports/Bloom AndCanning.pdf

The Institute for College Access and Success (20I4). Student debt and the class of 2013. Available at: http://ticas.org/sites/default/files/legacy/ fckfiles/pub/classof2or3.pdf

Usher, A. (2005). Global Debt Patterns: An International Comparison of Student Loan Burdens and Repayment Conditions. Canadian Higher Education Report Series, Educational Policy Institute. Toronto, Canada.

Williams, R. B., Benson, A., Bain, B., and Dicks, M. (2016, February). Factors affecting student load debt accrued by graduates of US veterinary medical colleges. Selected paper for 2016 annual meeting of the Southern Agricultural Economics Association, San Antonio, Texas.

Woodhall, M. (2004). Student loans: potential, problems, and lessons from international experience. Journal of Higher Education in Africa/Revue de l'enseignement supérieur en Afrique 2(2), 37-51.

Yusif, H. M., and Yussof, I. (20I0). Effects of the subsidized students' loan on university enrolment in Ghana. Journal of Science and Technology 30(2), 50-6r. doi: https://doi.org/10.4314/just.v30i2.670I7

Ziderman, A. (2013). Increasing access to higher education through student loans. CESifo DICE Report 2, II-I8.

Ziderman, A. (2002). Alternative objectives of national student loan schemes: Implications for design, evaluation and policy. The Welsh Journal of Education 11(I), 37-47. 